\title{
Aberrant CD200/CD200R1 expression and function in systemic lupus erythematosus contributes to abnormal T-cell responsiveness and dendritic cell activity
}

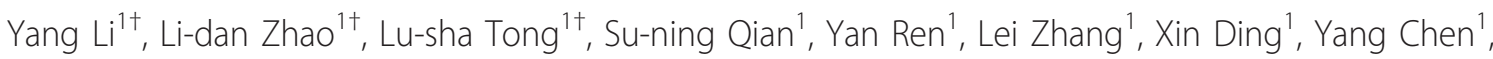
Yan-xia Wang ${ }^{1}$, Wen Zhang ${ }^{1}$, Xiao-feng Zeng ${ }^{1}$, Feng-chun Zhang ${ }^{1}$, Fu-lin Tang ${ }^{1}$, Xuan Zhang ${ }^{1 *}$, De-nian Ba ${ }^{2}$, Wei He${ }^{2}$, Xue-tao $\mathrm{Cao}^{2}$ and Peter E Lipsky ${ }^{3^{*}}$

\begin{abstract}
Introduction: CD200 is a type I transmembrane glycoprotein that can regulate the activation threshold of inflammatory immune responses, polarize cytokine production, and maintain immune homeostasis. We therefore evaluated the functional status of CD200/CD200 receptor 1 (CD200R1) interactions in subjects with systemic lupus erythematosus (SLE).

Methods: Serum CD200 level was detected by ELISA. The expression of CD200/CD200R1 by CD4 ${ }^{+} \mathrm{T}$ cells and dendritic cells (DCs) was examined by flow cytometry, and then compared between SLE patients and healthy controls. Peripheral blood mononuclear cells were stained with carboxyfluorescein diacetate succinimidyl ester and annexin V/propidium iodide for evaluation of the effect of CD200 on cell proliferation and apoptosis. In addition, the effect of CD200 on DC function was determined by transwell migration assay as well as by measurement of binding and phagocytosis of apoptotic cells.

Results: In SLE patients, the number of $\mathrm{CD}_{2} 00^{+}$cells and the level of soluble CD200 were significantly higher than in healthy controls, whereas the expression of CD200R1 by CD4 ${ }^{+} T$ cells and DCs was decreased. Furthermore, the increased CD200 expression by early apoptotic cells contributed to their diminished binding and phagocytosis by DCs in SLE. Importantly, the engagement of CD200 receptor on CD4 ${ }^{+} \mathrm{T}$ cells with CD200-Fc fusion protein in vitro reduced the differentiation of T-helper type 17 cells and reversed the defective induction of $\mathrm{CD} 4^{+} \mathrm{CD} 25^{\text {high }} \mathrm{FoxP}^{+} \mathrm{T}$ cells by transforming growth factor beta in SLE patients. Conversely, blockade of CD200-CD200R1 interaction with anti-CD200R1 antibody promoted CD4 ${ }^{+}$T-cell proliferation.
\end{abstract}

Conclusion: CD200 and CD200R1 expression and function are abnormal in SLE and may contribute to the immunologic abnormalities in SLE.

\footnotetext{
* Correspondence: zxpumch2003@yahoo.com.cn; peterlipsky@comcast.net

+ Contributed equally

'Department of Rheumatology \& Clinical Immunology, Peking Union

Medical College Hospital, Chinese Academy of Medical Sciences and Peking

Union Medical College, 41\# Da-Mu-Cang-Hu-Tong Street, Beijing 100032,

China

${ }^{3}$ Formerly National Institute of Arthritis and Musculoskeletal and Skin

Diseases, National Institutes of Health, 9000 Rockville Pike, Bethesda, MD

20892, USA

Full list of author information is available at the end of the article
} 


\section{Introduction}

Systemic lupus erythematosus (SLE) is an autoimmune disease that affects many tissues and organs. The major immunopathological findings of SLE include defective immune regulation with the breakdown of immune tolerance, autoantibody formation followed by immune complex deposition, cytokine imbalance, and inflammation [1]. Failure of phagocytes to remove apoptotic cells has been suggested to allow excessive release of autoantigens and to lead to the induction of autoimmunity, although the underlying mechanisms remain unclear [2-6]. In addition, $\mathrm{CD} 4^{+} \mathrm{CD} 25^{\text {high }} \mathrm{FoxP}^{+}$regulatory $\mathrm{T}$ cells (Tregs), which are pivotal in the maintenance of $\mathrm{T}$ cell homeostasis and are critical regulators of immune tolerance $[7,8]$, exhibit quantitative and/or qualitative deficiencies in SLE that may contribute to the development of lupus pathogenesis $[9,10]$.

CD200 is a type I transmembrane glycoprotein belonging to the immunoglobulin superfamily, and is expressed by a variety of cells, including B cells, activated $\mathrm{T}$ cells, follicular dendritic cells (DCs), and neurons [11-13]. CD200 consists of extracellular, transmembrane, and intracellular domains, although its intracellular region lacks a signaling motif [11-13]. CD200 receptors include CD200R1 to CD200R4, of which CD200R1 has the highest binding affinity [14]. The distribution of CD200 receptors is mainly on myeloid-derived cells, such as DCs, macrophages, and also activated T cells $[15,16]$. The known immunoregulatory roles of the CD200/ CD200R1 pathway include suppression of the degranulation of mast cells and basophils [17] and negative regulation of macrophage function [18].

Hoek and colleagues found that CD200-deficient mice had increased endogenous activation of macrophages/ myeloid cells in the central nervous system, with enhanced susceptibility to experimental allergic encephalomyelitis and collagen-induced arthritis [18]. Administration of CD200R-Ig to disrupt CD200CD200R interaction also increased the susceptibility of mice to collagen-induced arthritis. Furthermore, Broderick and colleagues reported that blockade of CD200 resulted in the early onset of experimental autoimmune uveoretinitis in mice [19]. In addition, Rosenblum and colleagues studied CD200-knockout mice in a model of $\mathrm{UV}$-mediated induction of tolerance to hapten, and suggested that the expression of CD200 in skin cells plays a role in autoimmune congenital alopecia [20]. Finally, Gorczynski and colleagues showed that tumor growth in vivo can be monitored by levels of soluble CD200 in serum of tumor-bearing animals [21], whereas Moreaux and colleagues found significant overexpression of CD200 in a variety of cancers compared with normal cells or tissues and suggested that CD200 might be a potential therapeutic target and prognostic factor for a large array of malignancies [22].

While available evidence highlighted an important role of CD200/CD200R1 in experimental autoimmune diseases, the role of CD200/CD200R1 in human autoimmune diseases such as SLE remains unknown. We therefore explored the expression and function of CD200/CD200R1 in subjects with SLE.

\section{Materials and methods \\ Patients and healthy controls}

Altogether, a total of 161 new-onset untreated patients fulfilling the American College of Rheumatology classification criteria for SLE were enrolled in this study. All were female, and their age ranged from 12 to 55 years with a mean age of $29.0 \pm 10.2$ years (see Additional file 1). Ninety-five gender-matched and age-matched healthy volunteers were recruited as healthy controls $(\mathrm{HCs})$. The Ethics Committee of Peking Union Medical College Hospital approved this study and informed consent was obtained from each patient and HC.

\section{Antibodies and reagents}

mAbs targeting the following molecules were used, either unlabeled or as fluorescein isothiocyanate, phycoerythrin, allophycocyanin, or phycoerythrin-cyanin 7 conjugates: CD4 (RPA-T4), CD11c (3.9), CD25 (BC96), CD200R (OX-108), CD38 (HIT2), and CD123 (6H6) from BioLegend (San Diego, CA, USA); IFN $\gamma$ (B27), CD3 (UCHT1), and CD28 (CD28.2) from BD Pharmingen (Franklin Lakes, NJ, USA); and CD200 (OX104), IL-4 (MP4-25), IL-17 (eBio64DEC17), and Foxp3 (PCH101) from eBioscience (San Diego, CA, USA). In all experiments, control $\mathrm{mAbs}$ of the respective IgG were included.

The CD200 Duoset and B-cell activating factor belonging to the TNF family, IFN $\alpha$, and IL-6 ELISA kits were purchased from R\&D Systems (Minneapolis, MN, USA). The Cell Trace ${ }^{\mathrm{TM}}$ carboxyfluorescein diacetate succinimidyl ester cell proliferation kit was obtained from Invitrogen (Carlsbad, CA, USA). Recombinant IL2 , IL-4, transforming growth factor beta (TGF- $\beta$ ) 1 , and granulocyte-macrophage colony-stimulating factor (GMCSF) were purchased from PeproTech Inc. (Rocky Hill, NJ, USA); PKH26, PKH67, ionomycin, and phorbol-12myristate-13-acetate were obtained from Sigma-Aldrich (St Louis, MO, USA); the Vybrant Apoptosis Assay Kit \#2 was obtained from Invitrogen; and recombinant human CD200-Fc, anti-human CD200 R1 antibody, and human IgG control were purchased from R\&D Systems.

\section{Enzyme-linked immunosorbent assay}

The levels of serum CD200, IL-6, IFN $\alpha$, and B-cell activating factor belonging to the TNF family were detected 
with ELISA kits according to the manufacturer's instructions.

\section{Real-time polymerase chain reaction}

Total RNA was isolated from peripheral blood mononuclear cells (PBMC) of SLE patients and HCs with TRIzol (Invitrogen), first-strand cDNA was synthesized, and the DNA amplification was detected with the dye SYBR Green (TAKARA, Otsu, Japan). Primers were as follows: for CD200, 5'-CCGTCAACAAAGGCTATTGG3' (forward) and 5'-ATTTAGGGCTCTCGGTCCTG-3' (reverse); for CD200R1, 5'-GACCAGAGAGGGTCTCACCA-3' (forward) and 5'-TTGAAGCGGCCACTAAGAAG-3' (reverse); and for glyceraldehyde-3-phosphate dehydrogenase, 5'-ACTTCAACAGCGACACCCACT-3' (forward) and 5'-GCCAAATTCGTTGTCATACCAG-3' (reverse).

\section{Cell culture, stimulation and treatment}

Cells were cultured in RPMI 1640 medium supplemented with $100 \mathrm{U} / \mathrm{ml}$ penicillin and $100 \mu \mathrm{g} / \mathrm{ml}$ streptomycin, $0.05 \mathrm{mM}$ nonessential amino acids, $2 \mathrm{mM}$ Lglutamine, as well as $10 \%$ heat-inactivated FCS in a humidified carbon dioxide-containing atmosphere at $37^{\circ}$ C. Cells were stimulated with anti-CD3 and anti-CD28 $\mathrm{mAbs}$ at $1 \mu \mathrm{g} / \mathrm{ml}$, respectively. Recombinant human CD200-Fc, anti-human CD200R1 antibody, and human IgG control were used at $100 \mathrm{ng} / \mathrm{ml}$; and recombinant human IL-2, TGF- $\beta$, IL-4, and GM-CSF were used at 20 $\mathrm{ng} / \mathrm{ml}, 2 \mathrm{ng} / \mathrm{ml}, 100 \mathrm{ng} / \mathrm{ml}$, and $100 \mathrm{ng} / \mathrm{ml}$, respectively. For T-cell differentiation experiments, PBMC were cocultured with CD200-Fc or anti-CD200R1 for 48 hours. Golgistop was added in the presence of phorbol-12-myristate-13-acetate and ionomycin 5 hours before cells were collected and stained for membrane molecules. Intracellular staining for IL-17, IL-4, and IFN $\gamma$ was also performed after fixation and permeabilization with fixation/permeabilization buffer. For cell proliferation assays, PBMC were stained with $5 \mu \mathrm{M}$ carboxyfluorescein diacetate succinimidyl ester, stimulated by antiCD3 and anti-CD28 mAbs alone or in the presence of CD200-Fc or anti-CD200R1, and cell proliferation was measured on day 5 by flow cytometry. The cell division index - which was defined as the ratio of the proportion of proliferated cells with decreased carboxyfluorescein diacetate succinimidyl ester fluorescence after stimulation to that without stimulation - was analyzed.

\section{Cell separation}

$\mathrm{CD} 4^{+} \mathrm{CD} 25^{-} \mathrm{T}$ cells and $\mathrm{CD} 14^{+}$monocytes were isolated using a $\mathrm{CD} 4{ }^{+} \mathrm{CD} 25^{+}$Regulatory $\mathrm{T}$ Cell Isolation Kit (130-091-301; Miltenyi Biotec) and CD14 MicroBeads (130-050-201; Miltenyi Biotec) according to the manufacturer's instructions. PBMC were induced to undergo apoptosis by X-ray accelerator (5 Gray) [23] and cultured in complete RPMI 1640 medium in a humidified carbon dioxide-containing atmosphere at $37^{\circ} \mathrm{C}$ for 48 hours. Apoptosis and necrosis were detected by annexin $\mathrm{V}$ and propidium iodide (PI) staining according to the manufacturer's protocol. $\mathrm{CD}^{-00}{ }^{+}$live cells, $\mathrm{CD}^{2} 20^{-}$live cells, CD200 ${ }^{+}$apoptotic cells, CD200 apoptotic cells, and necrotic cells were sorted by flow cytometry using the Moflo (Cytomation, Fort Collins, Colorado, USA). The sort gates were additionally restricted to the lymphocyte gate as determined by typical forward and sideward scatter characteristics $[24,25]$.

\section{Generation of dendritic cells}

Monocytes were cultured with recombinant human GM-CSF $(100 \mathrm{ng} / \mathrm{ml})$ and recombinant human IL-4 $(100 \mathrm{ng} / \mathrm{ml})$ and were harvested after 6 days. The monocyte-derived DCs were used for co-culture experiments and transwell assays.

\section{Cell staining and co-culture}

The monocyte-derived DCs and apoptotic and necrotic cell targets were labeled with green fluorescent dye PKH67 and red fluorescent dye PKH26 (Sigma-Aldrich), respectively, and then co-cultured (cell ratio $10^{4}: 10^{4}$ ) for 3 hours, after which they were analyzed by fluorescence microscopy and flow cytometry.

\section{Transwell migration assay}

The monocyte-derived DCs were seeded in the upper chambers of the transwell. The lower chambers were filled with IgG control (100 ng/ml), CD200Fc (100 ng/ $\mathrm{ml}$ ), RANTES (50 $\mathrm{ng} / \mathrm{ml}$ ) or CD200Fc plus RANTES. After 8 hours of incubation, the cells that had migrated to the lower chamber were counted.

\section{Western blot}

$\mathrm{CD} 4^{+} \mathrm{T}$ cells were cultured with recombinant human CD200Fc (IgG as control). After 5 days, cells were harvested, washed twice in ice-cold PBS, and lysed by incubation for 1 hour in a buffer containing $20 \mathrm{mM}$ HEPES (pH 7.9), $20 \%$ glycerol, $1 \%$ Nonidet P-40, $1 \mathrm{mM} \mathrm{MgCl}$, $0.5 \mathrm{mM}$ ethylenediamine tetraacetic acid, $0.1 \mathrm{mM}$ ethyleneglycol tetraacetic acid, $1 \mathrm{mM}$ dithiothreitol, $1 \mathrm{mM}$ phenylmethylsulfonyl fluoride and a proteinase inhibitor cocktail (BD Biosciences, Franklin Lakes, NJ, USA). Lysates were kept on ice and vortexed every 10 minutes for 1 hour before centrifugation at $13,000 \mathrm{rpm}$ and $4^{\circ} \mathrm{C}$. Equal amounts of protein were separated by SDS-PAGE (Invitrogen) and transferred to Immobilon PVDF membranes (Millipore, Billerica, Massachusetts, USA) and were blocked with 5\% dry milk in PBS containing 0.5\% Tween 20 before incubation with specific antibodies against downstream of tyrosine kinase 2 (DOK2; 
ab47507) or phosphorylated DOK2 (phospho Y299) (ab47376; Abcam, Cambridge, UK), followed by incubation with horseradish peroxidase-conjugated secondary antibody and development using Western Lightning Chemiluminescence Reagent Plus (PerkinElmer Life Sciences, Inc. Waltham, Massachusetts, USA).

\section{Statistical analysis}

All data were analyzed using SPSS 13.0 software. Data that passed both the Kolmogorov-Smirnov and the Shapira-Wilk tests $(P>0.05)$ were considered in a normal distribution. For data with normal distribution and homogeneity of variance (means and standard deviations), one-way analysis of variance with adjusted Bonferroni correction was used to assess the differences among groups. An independent-sample $t$ test and a paired-sample $t$ test were used to compare differences between two groups and differences before and after treatment. Correlation was calculated with Pearson's correlation. For data with a non-normal distribution (medians and 25th to 75th percentiles), the Mann-Whitney test was used to compare differences between two groups and correlation was analyzed with Spearman's rank-order test. $P<0.05$ was considered statistically significant.

\section{Results}

Increased CD200 but decreased CD200R1 expression by $\mathrm{CD}^{+} \mathrm{T}$ cells and dendritic cells in SLE patients

CD200 and CD200R1 expression was analyzed in SLE patients and HCs. The proportion of CD200 ${ }^{+}$cells in PBMC of SLE patients was significantly higher than that in $\mathrm{HCs}$ (Figure 1A, B), especially in the $\mathrm{CD} 4^{+} \mathrm{T}$-cell population, the $C D 11 c^{-} C D 123^{\text {high }}$ plasmacytoid DCs, and the $\mathrm{CD} 11 \mathrm{c}^{+} \mathrm{CD} 123^{-}$myeloid DCs (Figure 1B; see Additional file 2), but not in $\mathrm{CD} 8^{+} \mathrm{T}$ cells, $\mathrm{CD} 19^{+} \mathrm{B}$ cells, CD38 ${ }^{\text {bright }}$ plasma cells (data not shown), or CD14 ${ }^{+}$monocytes $(P>0.05)$. The percentage of $\mathrm{CD}^{+} \mathrm{CD} 200^{+}$ cells was negatively correlated with serum complement $3(r=-0.486, P<0.05$; Figure $2 \mathrm{~A})$. Unlike the cell numbers, there was no significant difference in the mean fluorescence intensities of CD200 expression between SLE patients and HCs in the different cell subgroups $(P$ $>0.05)$. Finally, even though the frequency of CD200expressing cells was increased in SLE, CD200 mRNA expression in PBMC was significantly lower in SLE patients than in HCs (Figure 1E).

In keeping with the increased percentage of cells expressing CD200, the circulating levels of CD200 in SLE patients were also significantly higher than that in $\mathrm{HCs}$ (median 142.22, interquartile range 82.26 to 469.29 vs. $76.62,45.9$ to $124.93 \mathrm{pg} / \mathrm{ml} ; P=0.001$ ). Furthermore, the serum CD200 level negatively correlated with the serum complement 3 level $(r=-0.45, P=0.014$; Figure
2B), but not the Systemic Lupus Erythematosus Disease Activity Index score or the levels of serum B-cell activating factor belonging to the TNF family, IL-6, IFNa, or anti-dsDNA $(P>0.05$; see Additional file 3$)$.

In contrast to CD200 expression, SLE patients had a decreased proportion of CD200R $1^{+}$cells in PBMC compared with HCs. This reduction was evident in $\mathrm{CD} 4^{+} \mathrm{T}$ cells, plasmacytoid DCs, and myeloid DCs (Figure 1C, D). CD200R1 mRNA expression in PBMC was also significantly lower in SLE patients than in HCs (Figure 1E). Of note, $\mathrm{CD}^{+}{ }^{+} \mathrm{CD} 45 \mathrm{RA}^{+}$naïve $\mathrm{T}$ cells had less CD200R1 expression than $\mathrm{CD}^{+} \mathrm{CD} 45 \mathrm{RO}^{+}$memory $\mathrm{T}$ cells in both HCs and SLE patients $(P<0.05)$, and there was no significant difference between SLE patients and HCs (see Additional file 4).

\section{Anti-CD200R1 antibody promotes T-cell receptor-driven proliferation of $\mathrm{CD}^{+} \mathrm{T}$ cells in SLE patients}

Next we set out to determine whether the defective CD200R1 expression by $\mathrm{CD} 4^{+} \mathrm{T}$ cells affects $\mathrm{CD} 4^{+} \mathrm{T}-$ cell function in SLE patients. As engagement of CD200R1 by CD200 is known to initiate signaling by inducing phosphorylation of docking protein 2 or the adaptor protein DOK2 (p56doc-2) [26], we initially determined whether soluble CD200Fc could influence CD200/CD200R1 signaling in CD4 $4^{+} \mathrm{T}$ cells by examining its effect on phosphorylation of DOK2. We found that CD200Fc induced phosphorylation of DOK2 in $\mathrm{CD}_{4}{ }^{+} \mathrm{T}$ cells. This result is consistent with previously reported findings and indicates that soluble CD200Fc by engaging CD200R is an agonist of the CD200/CD200R1 signaling pathway, whereas anti-CD200R1 antibody, according to the product instructions, is an antagonist and can block the receptor-ligand interaction (see Additional file 5).

Understanding the action of these reagents, we next examined their effects on the proliferation of $\mathrm{CD} 4^{+} \mathrm{T}$ cells. We found after stimulation with anti-CD3/CD28 that CD200-Fc did not cause a significant change in cellular proliferation (evaluated by the cell division index) in either SLE patients or HCs $(P>0.05$; Figure 3A). However, anti-CD200R1 promoted anti-CD3/CD28-stimulated proliferation of SLE CD4 ${ }^{+} \mathrm{T}$ cells in a concentration-dependent manner. In contrast, no effect was observed in HCs (Figure 3B). The cell division indexes in SLE T cells stimulated with anti-CD3/CD28 plus control IgG and with anti-CD3/CD28 plus anti-CD200R1 antibody at $20 \mathrm{ng} / \mathrm{ml}$ or $100 \mathrm{ng} / \mathrm{ml}$ were $0.87 \pm 0.54$, $1.43 \pm 0.92$, and $2.34 \pm 1.85$, respectively $(P<0.05)$. From this result, we concluded that antagonistic antiCD200R1 antibody promoted T-cell receptor-driven proliferation of $\mathrm{CD} 4^{+} \mathrm{T}$ cells in SLE patients, implying that endogenous CD200-CD200R1 interactions limited T-cell proliferation in SLE patients. 
A

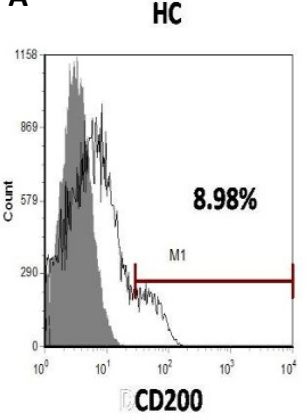

C
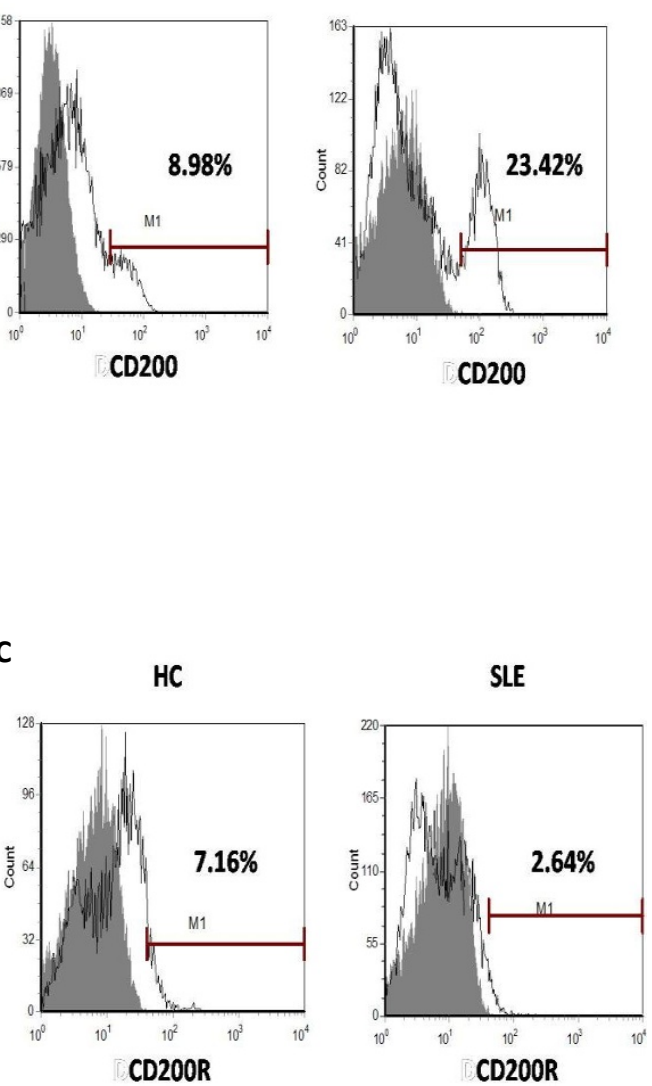

B

D

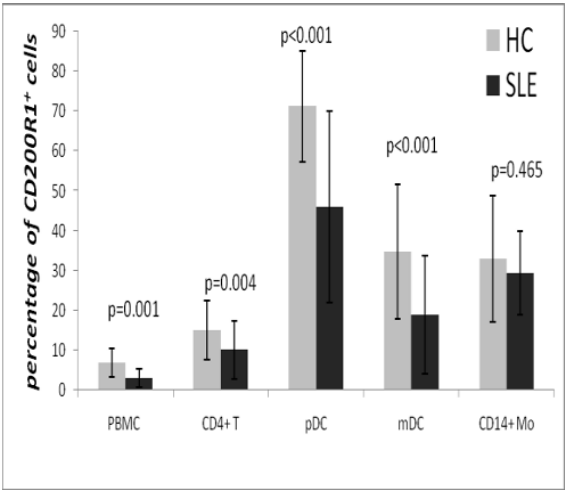

E
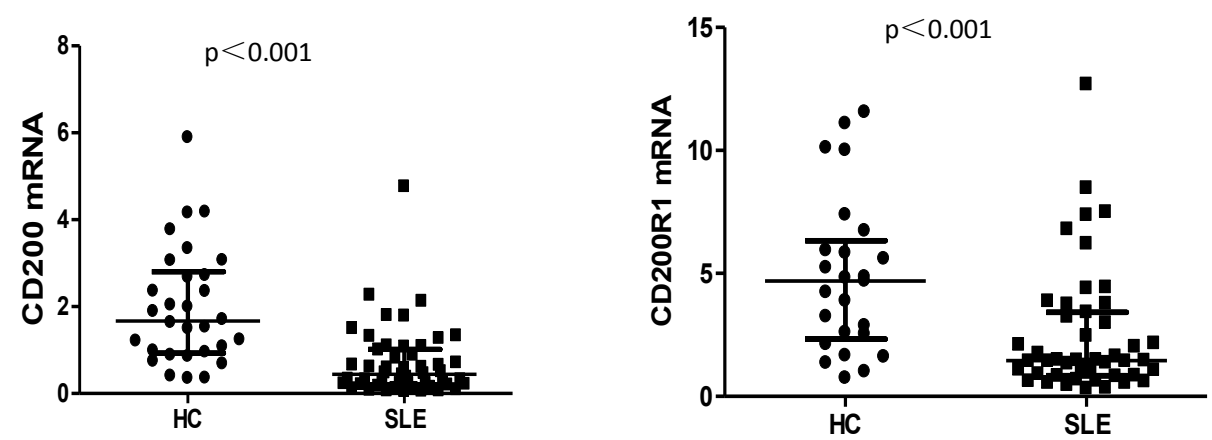

Figure 1 CD200 and CD200 receptor 1 expression in systemic lupus erythematosus patients and healthy controls. (A) CD200 expression in peripheral blood mononuclear cells (PBMC) was upregulated in systemic lupus erythematosus (SLE) patients. Open histogram: percentage of CD200 ${ }^{+}$cells in PBMC; gray histogram, IgG control. (B) Percentage of CD200 cells in PBMC (12.03 $\pm 9.67 \%$ vs. $\left.6.68 \pm 2.69 \%, P=0.026\right)$, CD4 ${ }^{+} \mathrm{T}$ cells $(9.17 \pm 3.26 \%$ vs. $6.45 \pm 2.82 \%, P=0.012), C D 14^{+}$monocytes, CD11 c ${ }^{-C D} 123^{\text {high }}$ plasmacytoid dendritic cells (pDCs) $(15.57 \pm 10.48 \%$ vs. 7.89 $\pm 4.26 \%, P=0.004)$ and $C D 11 c^{+} \mathrm{CD} 123^{-}$myeloid dendritic cells (mDCs) $(6.55 \pm 3.46 \%$ vs. $4.01 \pm 2.10 \%, P=0.016)$ from SLE patients $(n=53)$ and healthy controls (HCs) $(n=24)$. (C) CD200 receptor 1 (CD200R1) expression in PBMC was downregulated in SLE patients. Open histogram: percentage of CD200R $1^{+}$cells in PBMC; gray histogram, lgG control. (D) Percentage of CD200R $1^{+}$cells in PBMC $(3.10 \pm 2.24 \%$ vs.6.88 $\pm 3.61 \%, P$ $=0.001), C^{+} T$ cells $(10.11 \pm 7.37 \%$ vs. $15.08 \pm 7.50 \%, P=0.004), C D 14^{+}$monocytes, $C D 11 c^{-} C D 123^{\text {high }}$ pDCs $(45.93 \pm 24.07 \%$ vs. $71.28 \pm 13.91 \%$, $P<0.001)$ and $C D 11 c^{+} C D 123^{-}$mDCs $(18.91 \pm 14.90 \%$ vs. $34.75 \pm 16.82 \%, P<0.001)$ from SLE patients $(n=53)$ and HCS $(n=24)$. (E) mRNA expression of both CD200 (median 0.44 , interquartile range 0.20 to 1.02 vs. 1.67, 0.93 to $2.80 ; P<0.001$ ) and CD200R1 (median 1.45, interquartile range 0.85 to 3.42 vs. 4.69, 2.33 to 6.33; $P<0.001$ ) in PBMC was significantly lower in SLE patients than in HCs. 
A

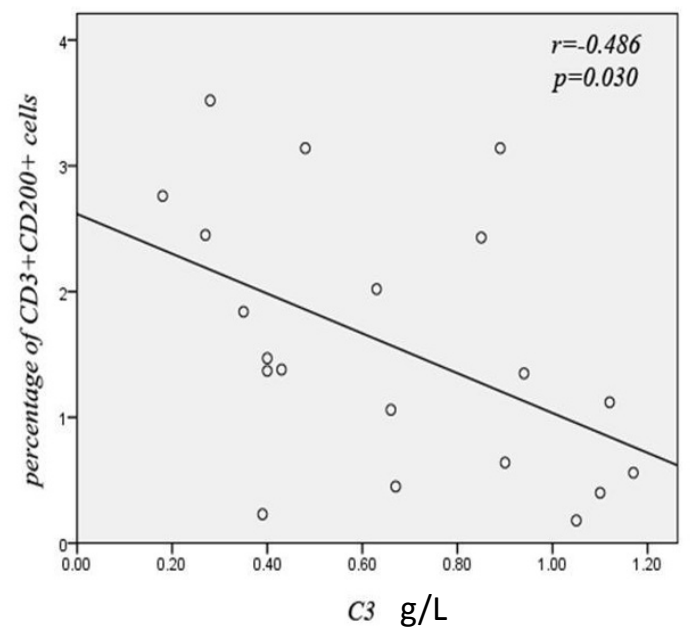

B

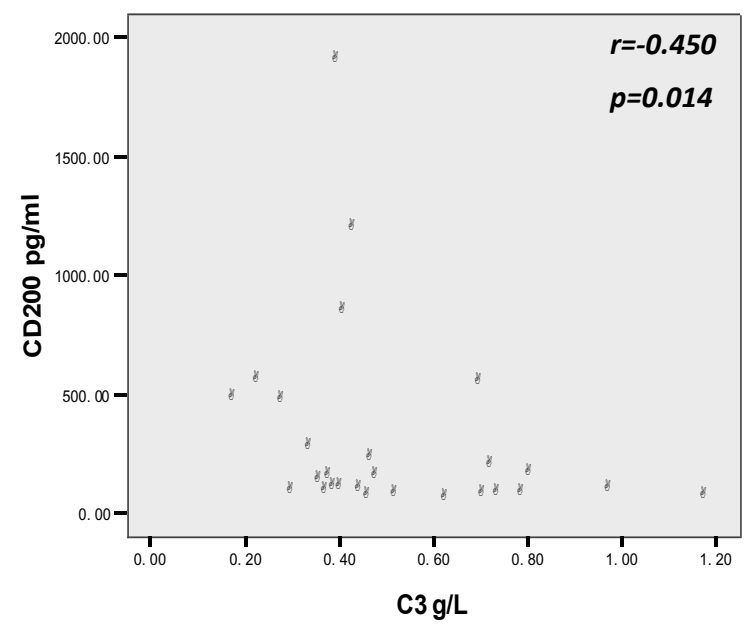

Figure 2 Correlation between CD200 and complement 3. (A) In systemic lupus erythematosus (SLE) patients, the proportion of $C D 3^{+} C D 200^{+}$ cells was negatively correlated with the serum complement 3 (C3) level $(r=-0.486, P<0.05)$. (B) Serum CD200 level was negatively correlated with serum C3 in SLE patients $(r=-0.45, P=0.014)$

\section{CD200 reduces $\mathrm{CD}^{+}$T-cell differentiation into T-helper type 17 cells}

The CD200/CD200R1 pathway has been suggested to affect the balance of cytokines, by repressing IL-2 (IFN $\gamma$ ) production and promoting IL-4 (IL-10) production, and to participate in transplantation tolerance [27]. We therefore investigated whether CD200-CD200R1 signaling could affect human $\mathrm{CD} 4^{+} \mathrm{T}$-cell differentiation. We found that, while the effect of the CD200-CD200R1 pathway on the T cells in HCs was negligible (see Additional file 6), CD200-Fc but not anti-CD200R1 reduced the percentage of Th17 cells $(P<0.05$; Figure 4$)$ in SLE patients, suggesting a role for CD200/CD200R signaling in regulating Th17 cell differentiation.

\section{CD200 signaling rescues the defective generation of CD4 ${ }^{+} \mathrm{CD}_{25} 5^{\text {high }} \mathrm{FoxP3}^{+} \mathrm{T}$ cells in SLE patients}

In a mouse collagen-induced arthritis model, the interaction between CD200 and CD200R1 resulted in direct suppression of autoreactivity, and fostered the development of Foxp $3^{+}$regulatory T cells [28]. TGF- $\beta$ induces Foxp3 gene expression in T-cell receptor-stimulated $\mathrm{CD} 4{ }^{+} \mathrm{CD} 25^{-}$naïve $\mathrm{T}$ cells, which mediates their transition toward a regulatory $\mathrm{T}$-cell phenotype with potent immunosuppressive potential [29]. We therefore examined whether CD200 played a role in the induction of Tregs in SLE patients. CD $4^{+} \mathrm{CD} 25^{-} \mathrm{T}$ cells were sorted from PBMC of SLE or HCs and were cultured with anti-CD3/CD28, IL- 2 and TGF- $\beta$ in the absence or presence of CD200-Fc or anti-CD200R1 for 7 days. We found that TGF- $\beta$ induced $\mathrm{CD} 4{ }^{+} \mathrm{CD} 25^{\text {high }} \mathrm{FoxP}^{+} \mathrm{T}$ cells from peripheral $\mathrm{CD} 4^{+} \mathrm{CD} 25^{-} \mathrm{T}$ cells in $\mathrm{HCs}$, but not in SLE patients. Notably, CD200Fc but not anti-CD200R1 rescued the defective induction of $\mathrm{CD} 4{ }^{+} \mathrm{CD} 25^{\text {high }} \mathrm{FoxP}^{+}$ $\mathrm{T}$ cells in SLE patients (Figure 5). In SLE patients, the percentages of induced $\mathrm{CD} 4{ }^{+} \mathrm{CD} 25^{\text {high }} \mathrm{Foxp}^{+} \mathrm{T}$ cells in TGF $-\beta+$ IgG and TGF- $\beta+$ CD200Fc groups were 0.93 $\pm 0.50 \%$ and $6.23 \pm 0.72 \%(P=0.013)$. We therefore concluded that the defective generation of CD4 ${ }^{+} \mathrm{CD} 25^{\text {high }} \mathrm{FoxP}^{+} \mathrm{T}$ cells in SLE patients could be rescued by enhanced CD200 signaling. This result suggests that the decreased expression of CD200R1 in SLE may contribute to the defective generation of Tregs.

\section{Increased lymphocyte apoptosis with upregulation of CD200 expression in SLE}

Next we were interested in determining whether CD200-CD200R interactions might also affect the activity of dendritic cells in SLE, and specifically their capacity to interact with apoptotic cells. Increased lymphocyte apoptosis and defective phagocytic removal of apoptotic cells have been suggested to contribute to the development of SLE [30-32]. We therefore initially examined whether CD200 expression by apoptotic cells was abnormal in SLE. Consistent with previous studies $[4,5,33]$, we demonstrated that the percentage of spontaneous early apoptotic lymphocytes (denoted as annexin $\mathrm{V}^{+} \mathrm{PI}^{-}$) in PBMC from SLE patients was significantly higher than that in HCs (Figure 6A). Interestingly, we found that CD200 expression by early apoptotic cells 
A
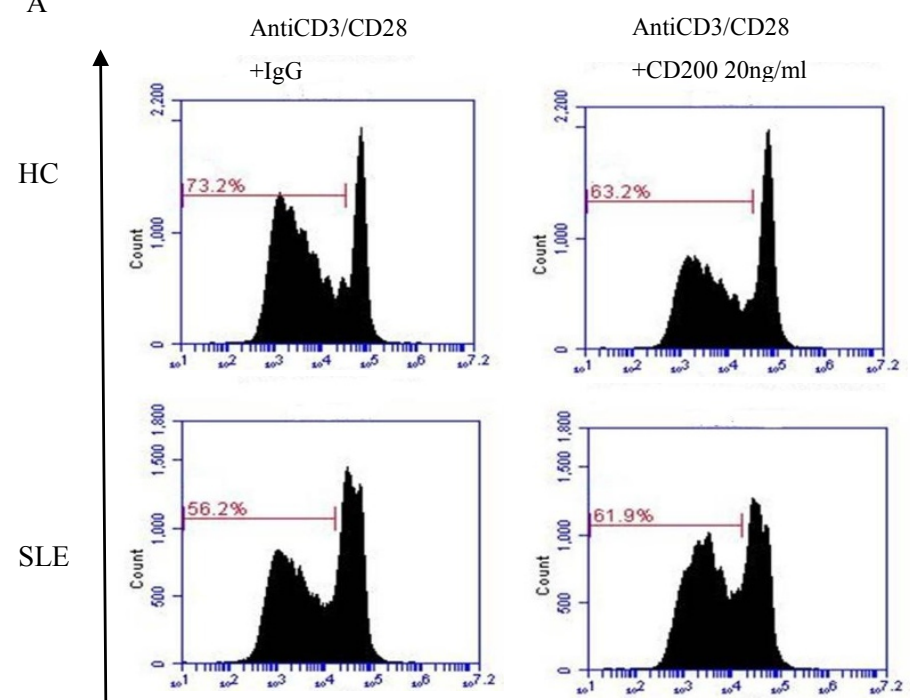

CFSE
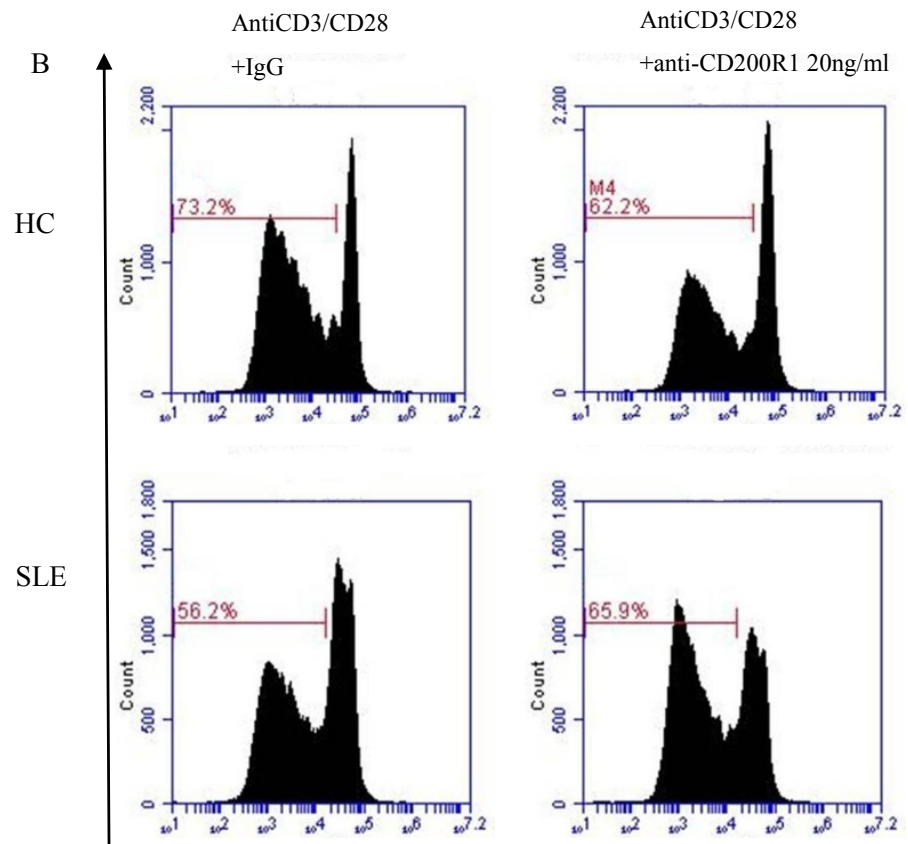
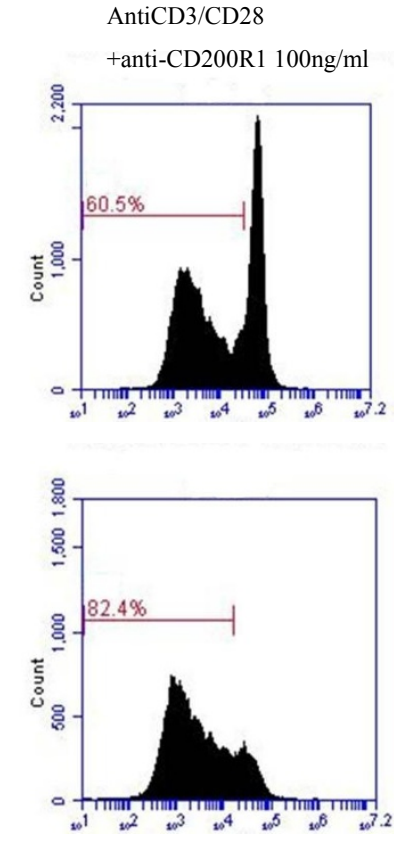

AntiCD3/CD28
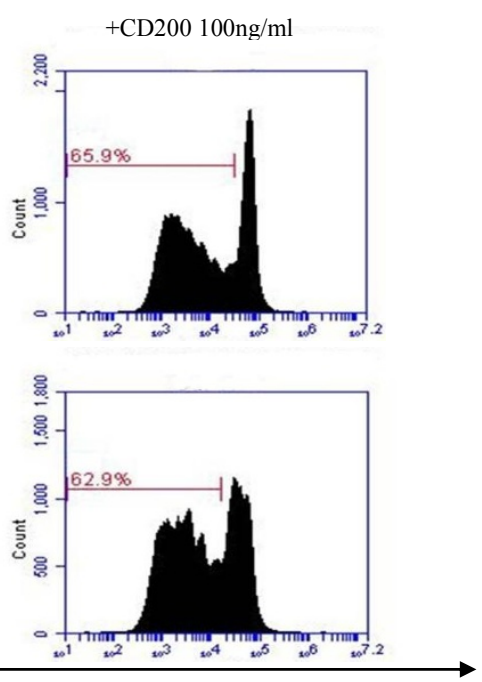

CFSE

Figure 3 Anti-CD200R1 antibody promoted T-cell receptor-driven proliferation of $\mathrm{CD}^{+} \mathrm{T}$ cells in systemic lupus erythematosus patients. (A) In systemic lupus erythematosus (SLE) patients and healthy controls (HCs), no significant difference in proliferation of anti-CD3/ CD28-stimulated CD4 ${ }^{+}$T cells was found in the presence of CD200Fc or lgG control. (B) In SLE patients, anti-CD200R1 promoted anti-CD3/CD28stimulated proliferation of $\mathrm{CD}^{+}{ }^{+} \mathrm{T}$ cells in a concentration-dependent manner, whereas this was not observed in HCs. Fluorescence-activated cell sorting (OK)plots are representative of five experiments performed on five SLE patients and HCs, respectively. CFSE, carboxyfluorescein diacetate succinimidyl ester. 
A

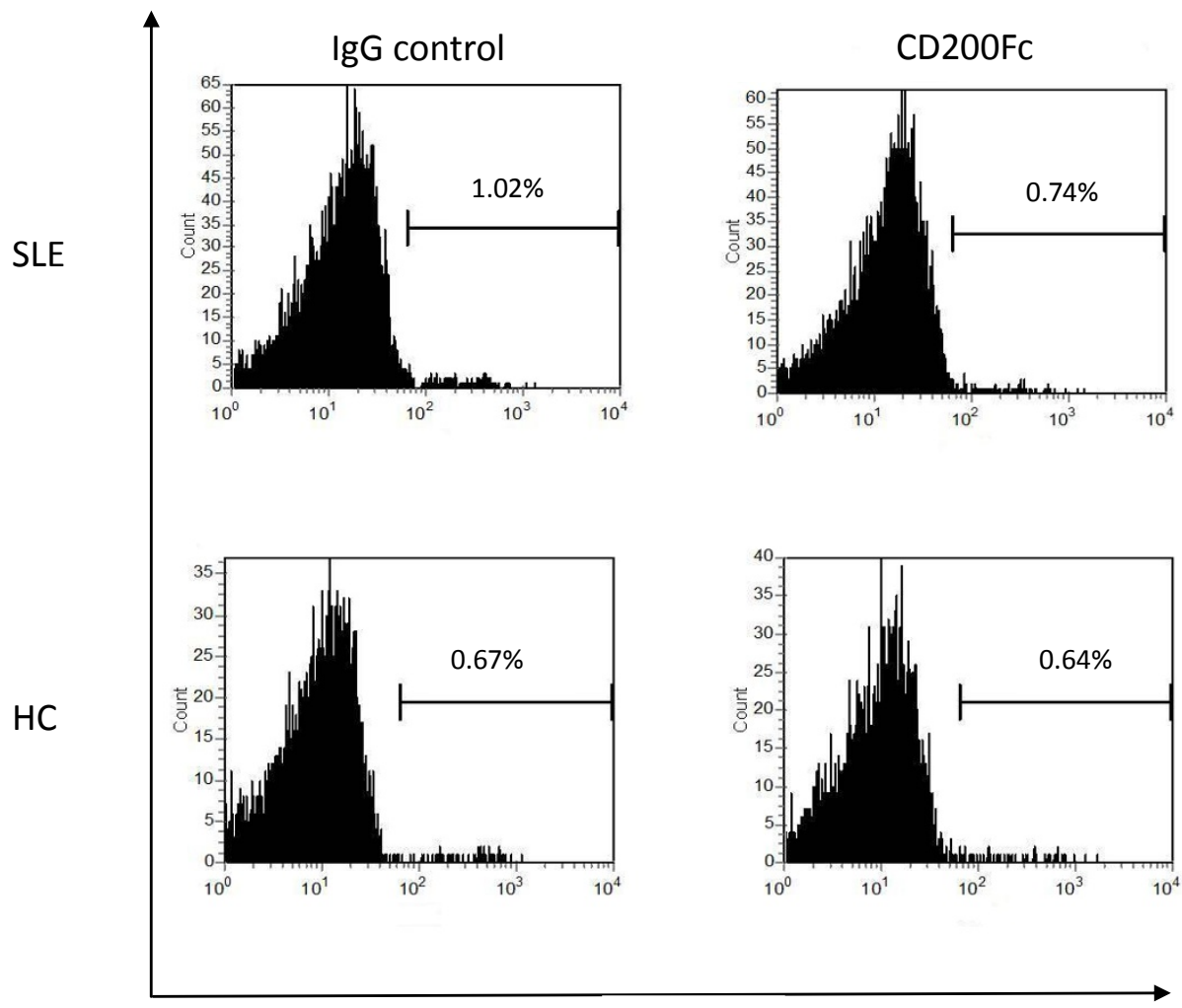

PE-IL-17

B

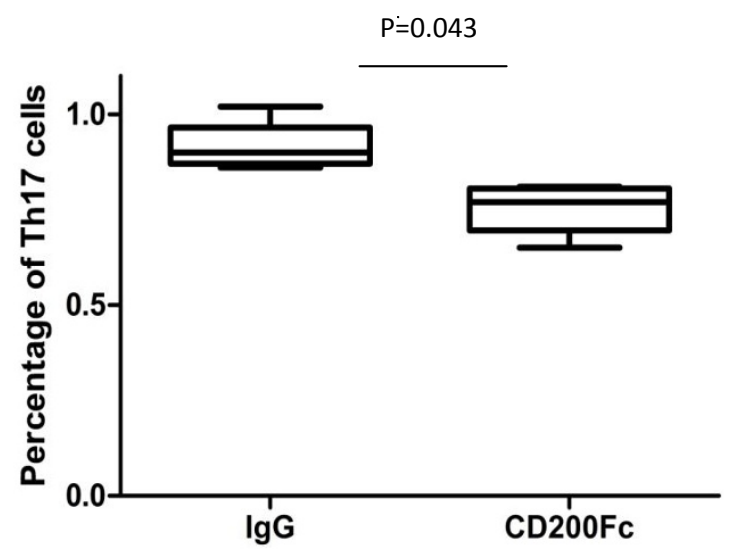

Figure 4 CD200Fc reduced T-helper type 17 cell differentiation in systemic lupus erythematosus patients. (A) Peripheral blood mononuclear cells from systemic lupus erythematosus (SLE) patients $(n=9)$ or healthy controls $(H C s)(n=6)$ were co-cultured with CD200FC for 48 hours. PE, phycoerythrin. (B) Percentages of T-helper type 17 (Th17) cells detected by flow cytometry. Numbers indicate the percentage of Th17 cells in CD4 ${ }^{+} \mathrm{T}$ cells. 


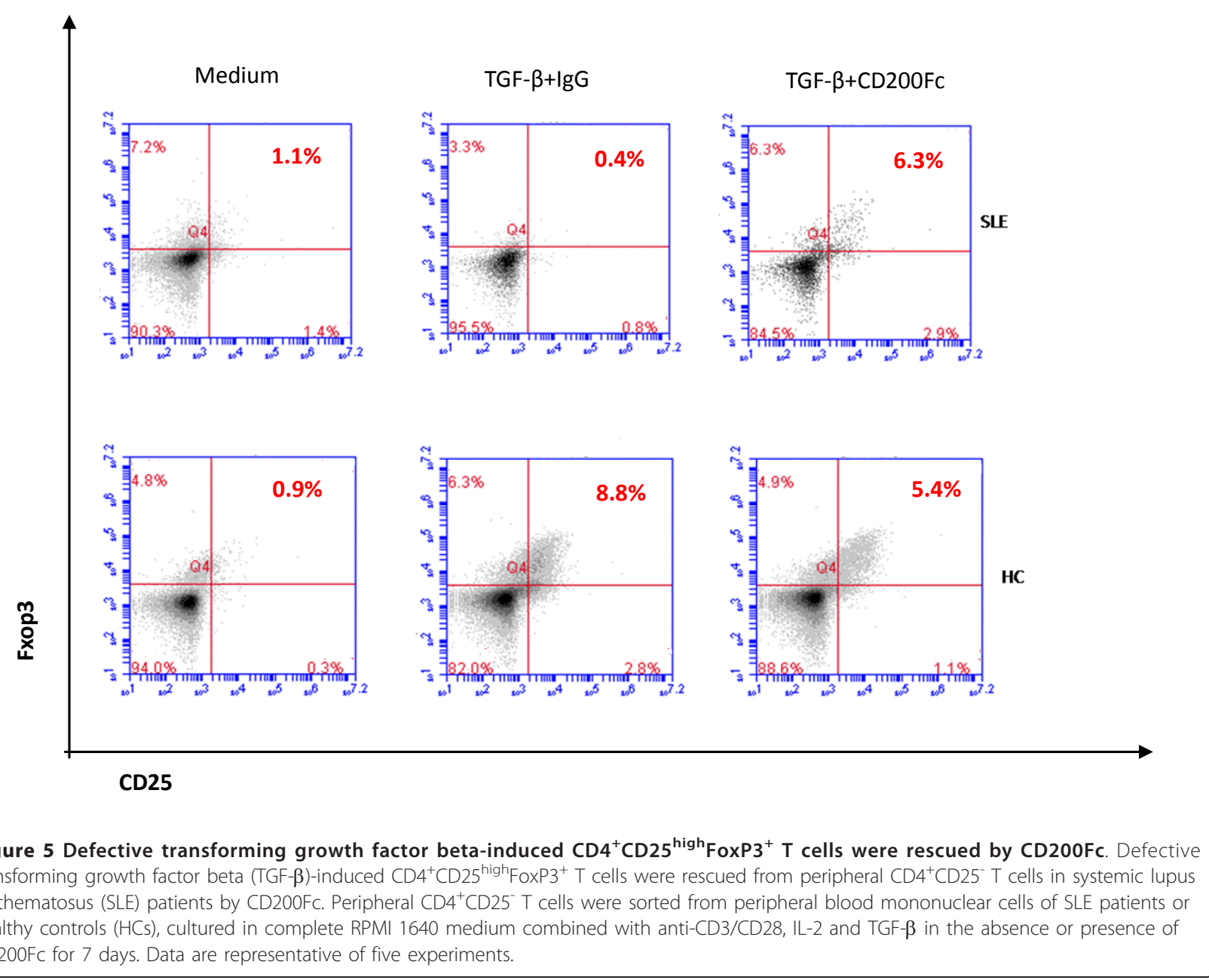

was significantly higher compared with that expressed by live cells (annexin $\mathrm{V}^{-} \mathrm{PI}^{-}$), especially in SLE patients. By comparison, there was no increase in CD4 expression on apoptotic $\mathrm{T}$ cells detected with a mAb labeled with the same fluorochrome used to detect CD200 (Figure 7). The CD200 relative expression ratio, defined as the ratio of CD200 positivity on early apoptotic cells compared with live cells, was significantly increased in SLE patients compared with HCs (Figure 6B).

We next investigated whether CD200 expression on apoptotic cells affected their binding and phagocytosis by DCs. We obtained immature DCs by culturing human monocytes with IL-4 and GM-CSF for 6 days [34]. The immature DCs (PKH67-labeled) were then co-cultured for 3 hours with different target cell populations (PKH26labeled), including $\mathrm{CD}^{2} 00^{+} / \mathrm{CD}^{2} 20^{-}$apoptotic cells induced by irradiation and $\mathrm{CD} 200^{+} / \mathrm{CD}^{-} 00^{-}$live cells, and were examined for cellular binding and uptake. We found that the proportion of DCs which bound and ingested apoptotic cells was higher compared with live cells. Importantly, CD200 expression on the target cells was associated with reduced binding and phagocytosis of apoptotic cells by DCs (Figures 8 and 9A). The percentages of DCs that bound and ingested $\mathrm{CD}^{2} 20^{-}$versus $\mathrm{CD} 200^{+}$apoptotic cells were $44.54 \pm 4.33 \%$ versus $36.76 \pm 6.09 \%$ by fluorescence microscopy $(P=0.037)$. By flow cytometry, the percentages of DCs that ingested CD200- versus $\mathrm{CD}^{-} 200^{+}$apoptotic cells - demonstrated as PKH26 and PKH67 doublepositive events - were $31.60 \pm 22.98 \%$ versus $21.71 \pm$ $20.20 \%(P=0.046)$. The results suggested that CD200 expression on early apoptotic cells is associated with decreased binding and phagocytosis by DCs.

\section{CD200Fc inhibits dendritic cell migration}

We were interested in whether CD200-CD200R interactions might affect other functional activities of DCs, and therefore examined the impact on DC migration. In initial experiments, we noted a potential effect of soluble 
A

HC

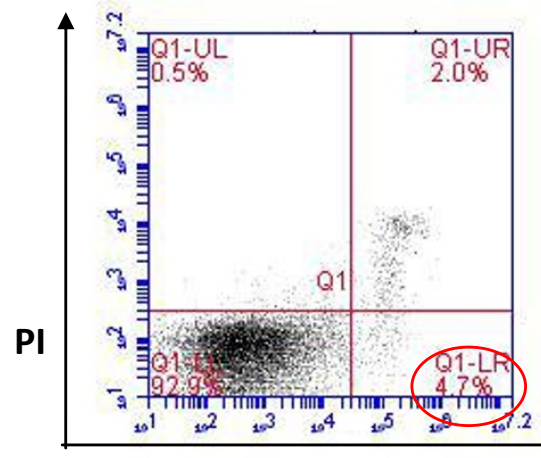

Annexin V
SLE

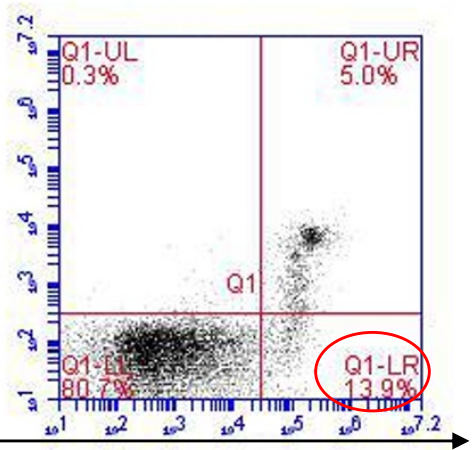

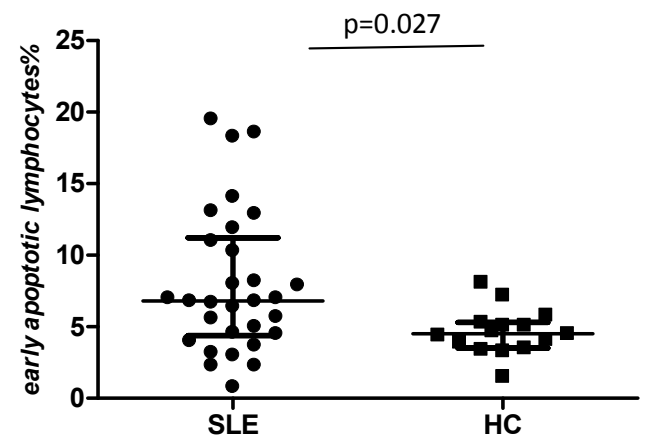

B

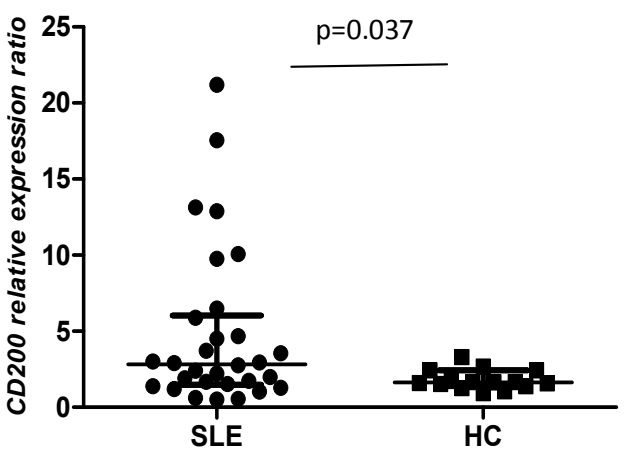

Figure 6 Increased lymphocyte apoptosis with upregulation of CD200 expression in systemic lupus erythematosus. (A) Percentage of spontaneous early apoptotic lymphocytes (annexin $\mathrm{V}^{+} \mathrm{Pl}^{-}$) in peripheral blood mononuclear cells from systemic lupus erythematosus (SLE) patients $(n=30)$ was significantly higher than in healthy controls (HCs) $(n=15)$ (median 6.80, interquartile range 4.38 to 11.23 vs. $4.50,3.50$ to 5.30; $P=0.027$ ). (B) CD200 relative expression ratio, defined as the percentage of CD200 positivity on early apoptotic cells to live cells, was significantly increased in SLE patients compared with HCs (median 2.83, interquartile range 1.50 to 6.04 vs. 1.64, 1.38 to 2.42; $P=0.037$ ). PI, propidium iodide. 


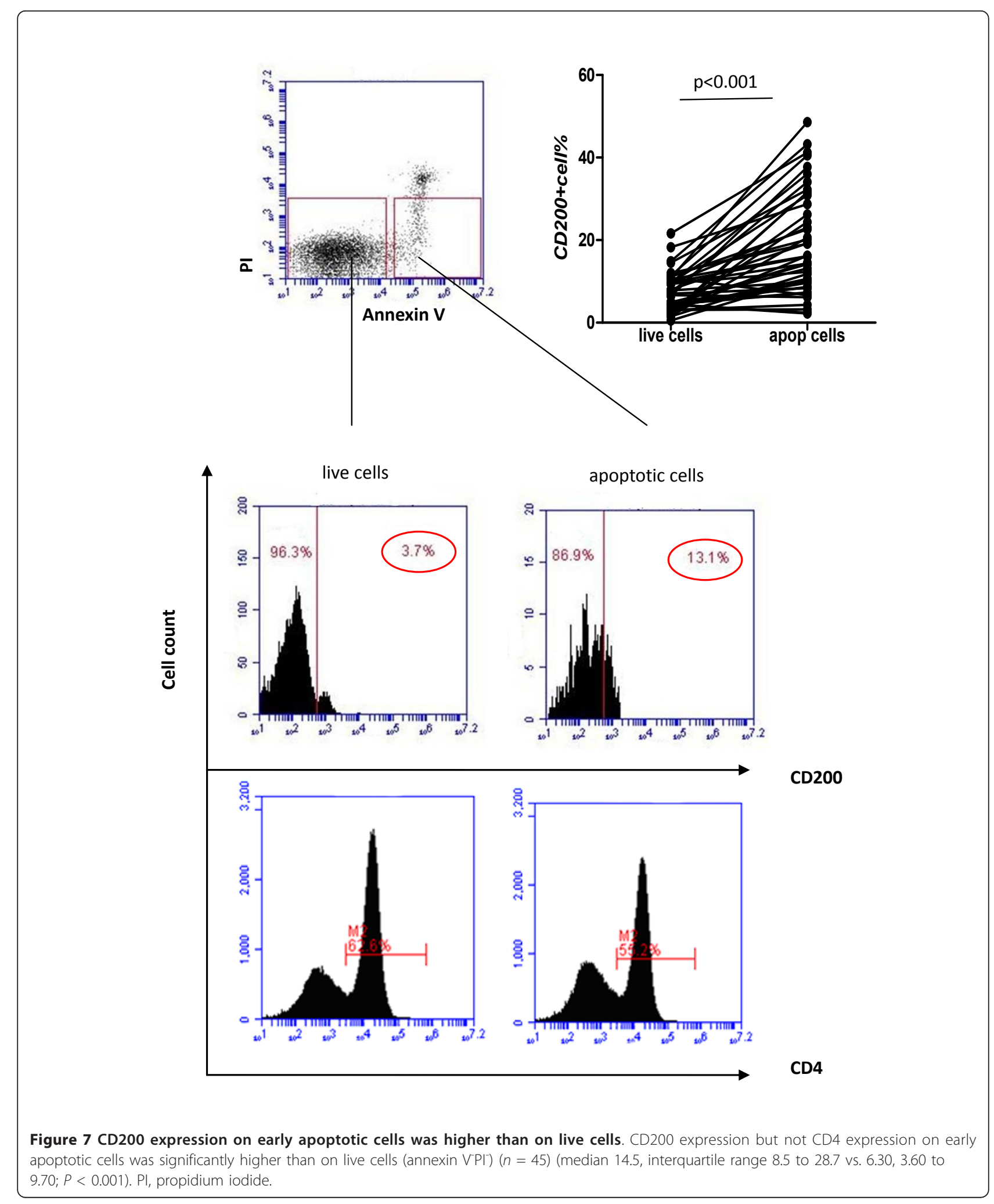

CD200Fc itself in reducing spontaneous DC migration although the effect was not statistically significant (IgG vs. CD200Fc, $6.21 \pm 2.23 \%$ vs. $4.38 \pm 2.42 \%$ migrated; $P=$
0.224). However, CD200Fc significantly blocked RANTESinduced DC migration (IgG vs. CD200Fc, $10.32 \pm 2.94 \%$ vs. $7.16 \pm 2.36 \%$ migrated; $P=0.029$; Figure $9 \mathrm{~B}$ ). 

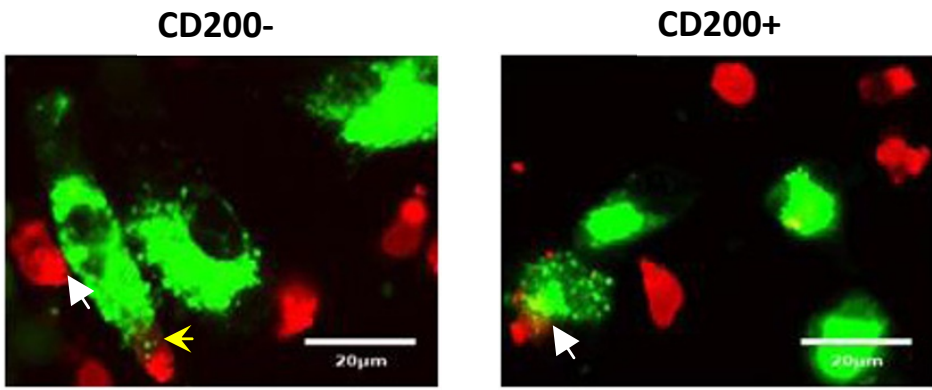

\section{DC\&}

Live cells
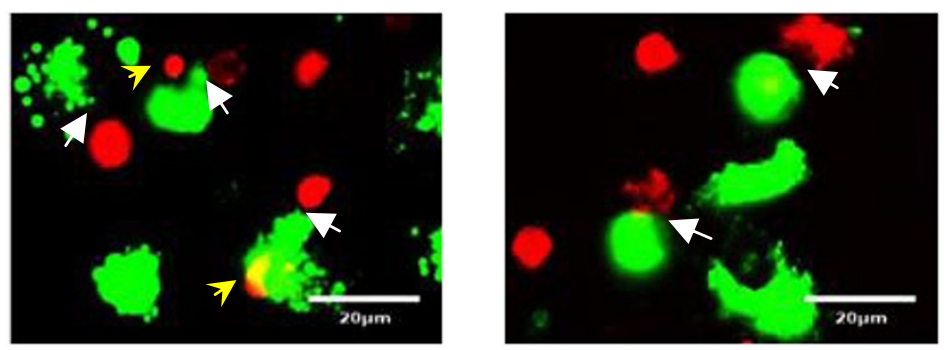

DC\&

Apoptotic cells

B

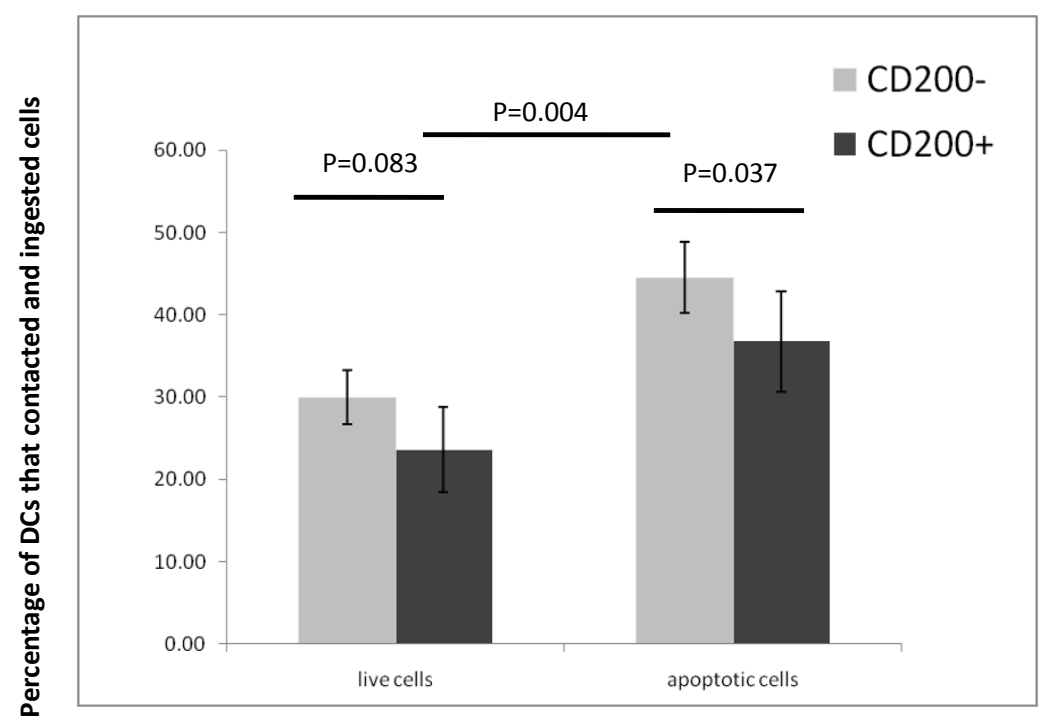

Figure 8 CD200 expression on apoptotic cells affected their binding and phagocytosis by dendritic cells. (A) Immature dendritic cells (DCs) (stained with PKH67, green) were incubated with target cells pre-labeled with PKH26 (red) and examined under immunofluorescence microscopy. White arrowheads, target cells attached to immature DCs; yellow arrowheads, target cells engulfed by immature DCs. Upper left,

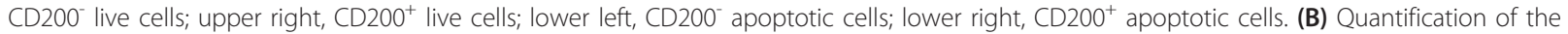
percentages of DCs that bound and ingested target cells by immunofluorescence microscopy. The percentages were calculated by counting all the cells in 10 microscope fields (average 40 to 50 cells each microscope field and 400 to 500 cells were recorded in total). 
A

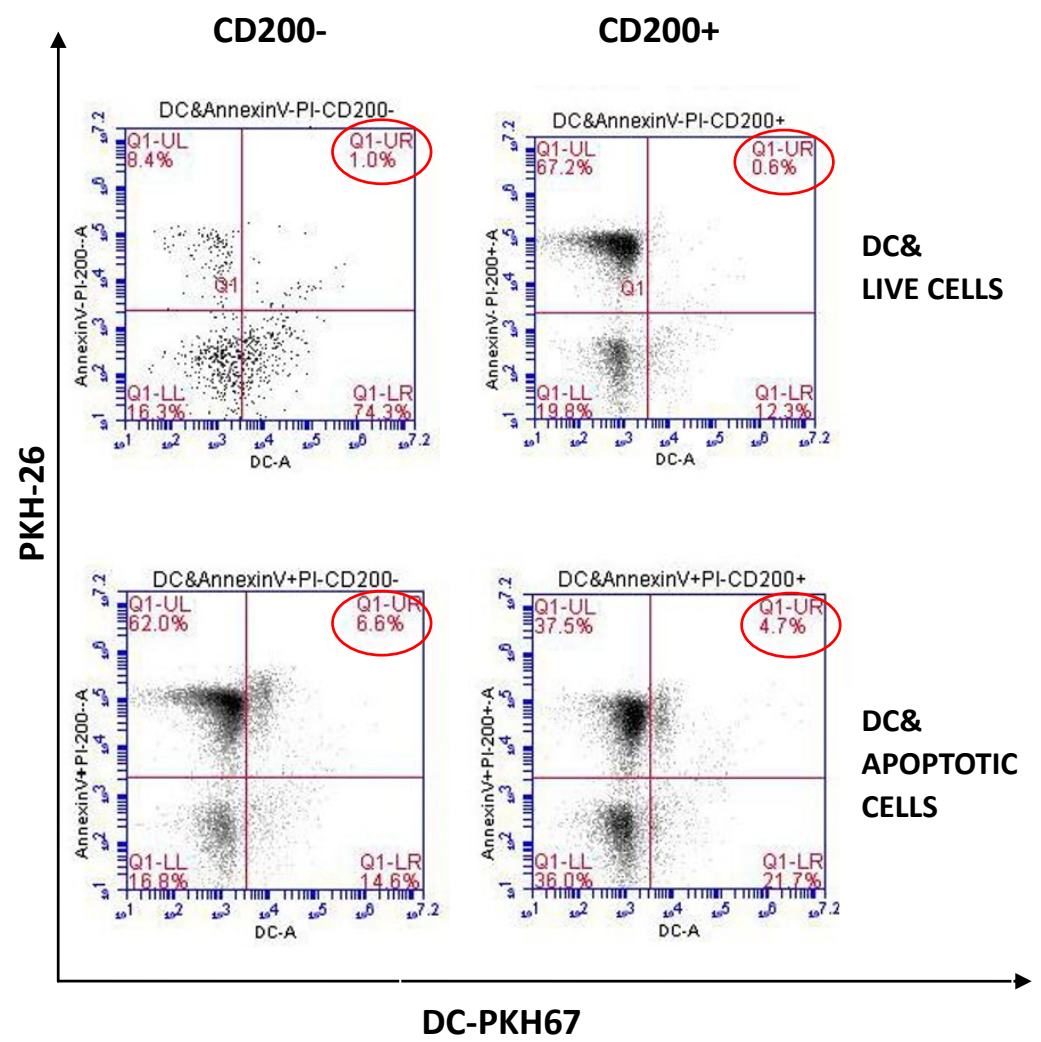

B

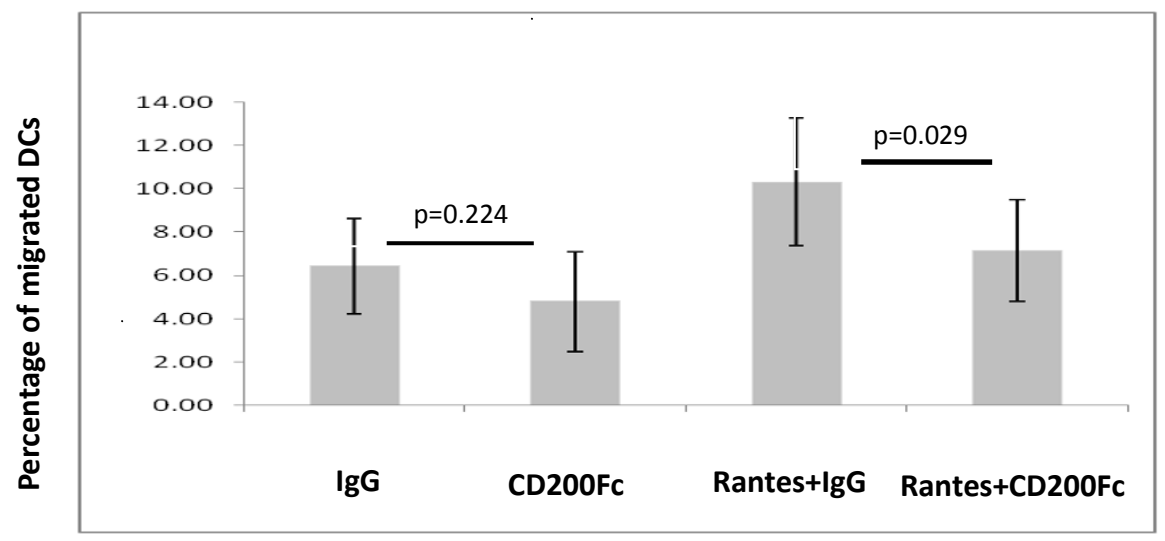

Figure 9 CD200Fc reduced dendritic cell migration and ingestion of early apoptotic cells. (A) Quantification of the percentages of dendritic cells (DCs) that ingested target cells by flow cytometry. PKH26/PKH67 double-positive cells indicated DCs that ingested target cells. (B) Percentage of DCs that migrated by transwell experiment $(n=5)$. PI, propidium iodide; RANTES, regulated on activation, normal T-cell expressed and secreted (OK). 


\section{Discussion}

Despite the data in animal models - including collageninduced arthritis and experimental allergic encephalomyelitis - suggesting that CD200/CD200R1 may play a role in prevention of autoimmune diseases, information on the role of the CD200/CD200R axis in human diseases - especially in SLE - is very limited. Our study demonstrated that the percentage of $\mathrm{CD}_{2} 200^{+}$cells in CD4 $4^{+} \mathrm{T}$ cells, plasmacytoid DCs and myeloid DCs of SLE patients was significantly higher than that for HCs. In addition, serum levels of CD200 in SLE patients were also significantly higher than those for HCs.

As CD200 lacks an intracellular signaling motif, most - if not all - of its immunological function relates to its capacity to engage and signal via its receptors, of which CD200R1 seems to be most prominent. Functional studies confirmed this by showing that CD200Fc induced phosphorylation of DOK2 in $\mathrm{CD} 4^{+} \mathrm{T}$ cells. Notably, we found that CD200R1 expression in SLE patients was significantly lower than $\mathrm{HCs}$ in $\mathrm{CD} 4^{+} \mathrm{T}$ cells and DCs. The dysregulated expression of CD200/CD200R1 in SLE had functional consequences since $\mathrm{CD} 4^{+} \mathrm{T}$-cell proliferation was increased by blocking CD200R1 with specific antibody, whereas DC migration and Th17 cell differentiation were decreased and Treg generation was enhanced by engaging CD200R with CD200Fc. These results are all consistent with the conclusion that the deranged expression of both CD200 and CD200R1 in SLE contributes to the functional abnormalities characteristic of this autoimmune disease. Notably, most of the activity of CD200-CD200R1 engagement is usually believed to relate to inhibiting the activity of myeloid cell function [35]. However, we found that CD200R1 expression was also decreased on $\mathrm{CD} 4^{+} \mathrm{T}$ cells and at least the activity in regulating Tregs appeared to involve a direct effect on $\mathrm{T}$ cells. These findings suggest a broader spectrum of activity of CD200R1 signaling than has previously been appreciated.

Overproduction of autoantibodies in SLE is believed to be caused by insufficient removal of apoptotic cells and material by macrophages and DCs. Our study demonstrated that SLE patients had a higher proportion of spontaneous early apoptotic lymphocytes compared with HCs. The amount of apoptotic material in SLE patients may exceed the capacity of macrophages to remove it, allowing DCs to become involved in the process of apoptotic cell clearance. Under these circumstances, DCs can become either tolerogenic or stimulatory, depending on the nature of the receptors employed and the available cytokines. As CD200 expression on early apoptotic lymphocytes was increased in SLE patients, we examined whether the increased expression of CD200 on early apoptotic lymphocytes might have had an effect on their binding and uptake by DCs. We demonstrated that early apoptotic cells were more likely to be bound and engulfed by DCs than living cells. The explanation for this could be that although early apoptotic cells remain morphologically intact, specific signals - such as expression of lysophosphatidylcholine - were upregulated on the cell surface, which mediated recognition by DCs and macrophages [36,37]. Our study also revealed that the binding and phagocytosis of early apoptotic cells that were CD200-positive were lower than those that did not express CD200, suggesting that CD200 expression in SLE could provide a signal to DCs - presumably by binding CD200R, which limits their capacity to bind and ingest apoptotic material. Aberrant expression of CD200 may therefore contribute to the decreased clearance of apoptotic material found in SLE.

To function, CD200 needs to bind to CD200R on cell surfaces. Our data confirmed that $\mathrm{T}$ cells expressed CD200R1. Since a previous animal study suggested that CD200/CD200R signaling had an effect on cytokine balance [27], we investigated whether CD200/CD200R1 could affect the balance of T-cell subsets in SLE. We found that CD200Fc reduced Th17 cell differentiation in SLE, but not in HCs. These results suggest that Th17 cell differentiation in SLE may be regulated by engagement of CD200R, such that signaling through this pathway limited Th17 cell differentiation. It is possible that the downregulation of CD200R in SLE resulted in less regulation of Th17 cell differentiation, which could be corrected by the increased availability of CD200. On the contrary, anti-CD3/CD28-stimulated T-cell proliferation was promoted by antagonistic anti-CD200R1 in a concentration-dependent manner in SLE patients but not HCs, suggesting that anti-CD200R1 may block the endogenous signal provided by increased expression of CD200 and, thereby, permit increased CD $4^{+} \mathrm{T}$-cell proliferation. In summary, these results indicate that the CD200-CD200R1 pathway exerts a number of regulatory influences on $\mathrm{T}$-cell function, either directly or through the action of DCs, and that the dysregulation of surface expression of these molecules may contribute to some of the immunoregulatory abnormalities characteristic of SLE.

In untreated active SLE patients, the proportion of $\mathrm{CD} 4{ }^{+} \mathrm{CD} 25^{\text {high }} \mathrm{FoxP} 3^{+}$Tregs was significantly lower than in HCs (see Additional file 7). Pallasch and colleagues demonstrated that antagonistic anti-CD200 antibody could promote chronic lymphocytic leukemia cellinduced proliferation of antigen-specific $\mathrm{T}$ cells and reduce the proportion of $\mathrm{CD} 4{ }^{+} \mathrm{CD} 25^{\text {high }} \mathrm{FoxP}^{+}$cells [38]. Gorczynski and colleagues showed that, in BL/6 bone-marrow cells, anti-CD200R2/3 mAb (not CD200R1) could promote the development of 
tolerogenic DCs through a TGF- $\beta$-dependent (but not IL-10) and CTLA-4-dependent pathway, induce more $\mathrm{CD} 4{ }^{+} \mathrm{CD} 25^{\text {high }} \mathrm{FoxP}^{+}$Tregs, and inhibit the mixed lymphocyte reaction in a MHC-restricted and antigen-specific manner [39]. These results all suggested that the activation of the CD200/CD200R axis could exert an immunosuppressive function via promoting Treg proliferation and inhibiting effector T-cell function. Our study found that TGF- $\beta$ induced generation of CD4 ${ }^{+} \mathrm{CD} 25^{\text {high }} \mathrm{FoxP}^{+} \mathrm{T}$ cells in $\mathrm{HCs}$, whereas this was not seen in SLE patients. This finding is consistent with a previous study that demonstrated defective expression of TGF- $\beta$ signal transduction molecules in most SLE patients [40]. Interestingly, we found that the addition of CD200Fc rescued the defective generation of CD4 ${ }^{+} \mathrm{CD} 25^{\text {high }} \mathrm{FoxP}^{+} \mathrm{T}$ cells in SLE patients, indicating that CD200 could intervene in the TGF- $\beta$ signaling pathway and promote Treg generation. This effect appeared to be directly mediated by $\mathrm{T}$ cell- $\mathrm{T}$ cell interaction since these studies were carried out with sorted T cells. Specific signals and cytokines mediate the differentiation of Tregs and Th17 cells [41,42]. The current data imply that signaling through CD200R1 may be one important influence on these pathways of $\mathrm{T}$-cell differentiation. Increased signaling through CD200R1 may bias toward Tregs and away from Th17 cells, and thus may be beneficial in SLE.

Downregulation of CD200R1 in SLE may contribute to impaired generation of regulatory signals, and increased production of CD200 in vivo could bind to other receptors such as CD200R2 to CDR200R4 [14], thereby transmitting stimulatory signals leading to the enhanced differentiation of Th17 cells, as has been reported [43]. Moreover, it has been reported that CD200 engagement of CD200R1 could induce tolerogenic DCs, which in turn could promote differentiation of Tregs $[39,44,45]$.

In our study, however, experiments were carried out with purified $\mathrm{T}$ cells, making this a less probable explanation for the findings. CD200R1 expression by DCs was also downregulated in SLE, however, suggesting that reduced generation of tolerogenic DCs in the context of decreased Tregs could contribute to unregulated development of Th17 cells.

\section{Conclusions}

Taking the results together, we have demonstrated in SLE patients that the number of $\mathrm{CD} 200^{+}$cells as well as the serum level of CD200 were significantly higher than in HCs, whereas CD200R1 expression was significantly lower than in HCs, especially in $\mathrm{CD} 4^{+} \mathrm{T}$ cells and DCs. In addition, in SLE patients, exogenous CD200Fc reduced the proportion of Th17 cells and rescued the defective generation of $\mathrm{CD} 4{ }^{+} \mathrm{CD} 25^{\text {high }} \mathrm{FoxP}^{+} \mathrm{T}$ cells, whereas anti-CD200R1 antibody promoted anti-CD3/
CD28-induced CD4 ${ }^{+} \mathrm{T}$-cell proliferation. Moreover, we found that CD200 on early apoptotic cells was increased in SLE patients and may serve to limit their binding and phagocytosis by DCs. These data collectively indicate that CD200 and CD200R1 expression and function are abnormal in SLE and may contribute to the immunologic abnormalities in this autoimmune disease.

\section{Additional material}

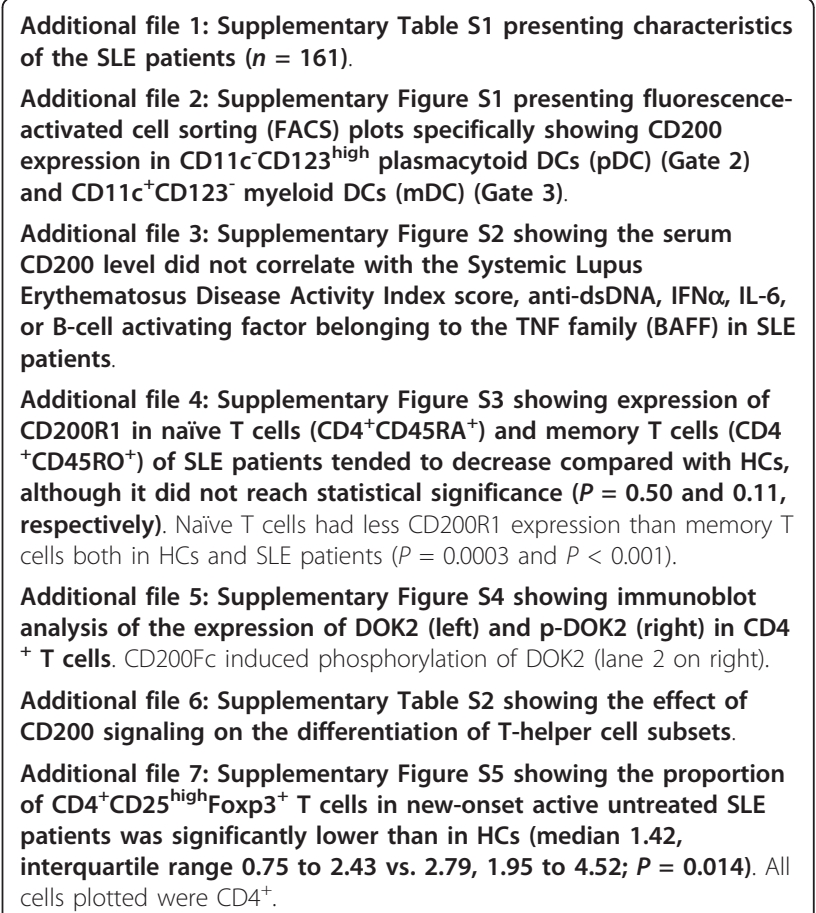

\section{Abbreviations}

CD200R1: CD200 receptor 1; DC: dendritic cell; DOK2: downstream of tyrosine kinase 2; dsDNA: double-stranded DNA; ELISA: enzyme-linked immunosorbent assay; FCS: fetal calf serum; GM-CSF: granulocyte-

macrophage colony-stimulating factor; HC: healthy control; IFN: interferon; IL: interleukin; mAb: monoclonal antibody; PBMC: peripheral blood

mononuclear cells; PBS: phosphate-buffered saline; PI: propidium iodide; RANTES: regulated on activation, normal T-cell expressed and secreted; SLE: systemic lupus erythematosus; TGF- $\beta$ : transforming growth factor beta; Th17: T-helper type 17; TNF: tumor necrosis factor; Treg: regulatory $T$ cell.

\section{Acknowledgements}

The authors wish to thank the health professional staff from Department of Rheumatology, Peking Union Medical College Hospital and the patients for their participation in the study, and thank Dr Wanjun Chen from NIDCR, NIH, Bethesda, MD, USA for his helpful discussion and critical reading of the manuscript.

\section{Author details}

'Department of Rheumatology \& Clinical Immunology, Peking Union Medical College Hospital, Chinese Academy of Medical Sciences and Peking Union Medical College, 41\# Da-Mu-Cang-Hu-Tong Street, Beijing 100032, China. ${ }^{2}$ Department of Immunology, School of Basic Medicine, Peking Union Medical College, Institute of Basic Medical Sciences, Chinese Academy of Medical Sciences, \#5 Dong-Dan-San-Tiao, Beijing 100005, China. ${ }^{3}$ Formerly 
National Institute of Arthritis and Musculoskeletal and Skin Diseases, National Institutes of Health, 9000 Rockville Pike, Bethesda, MD 20892, USA.

\section{Authors' contributions}

$Y L, L-d Z$, and L-sT developed the study, analyzed the data and drafted the manuscript. S-nQ, YR, LZ, XD, YC, and Y-xW participated in the data collection and performed the data analysis. WZ, X-fZ, F-cZ, and F-IT participated in the enrollment of patients. $X Z$ and PEL designed the study, participated in the data analysis and manuscript preparation. $\mathrm{D}-\mathrm{nB}, \mathrm{WH}$, and $\mathrm{X}$-tC participated in coordination of the study. All authors read and approved the final manuscript.

\section{Competing interests}

The authors declare that they have no competing interests.

Received: 17 February 2012 Revised: 17 April 2012

Accepted: 23 May 2012 Published: 23 May 2012

\section{References}

1. Rahman A, Isenberg DA: Systemic lupus erythematosus. N Engl J Med 2008, 358:929-939

2. Gaipl US, Munoz LE, Grossmayer G, Lauber K, Franz S, Sarter K, Voll RE, Winkler T, Kuhn A, Kalden J, Kern P, Herrmann M: Clearance deficiency and systemic lupus erythematosus (SLE). J Autoimmun 2007, 28:114-121.

3. Herrmann M, Voll RE, Zoller OM, Hagenhofer M, Ponner BB, Kalden JR: Impaired phagocytosis of apoptotic cell material by monocyte-derived macrophages from patients with systemic lupus erythematosus. Arthritis Rheum 1998, 41:1241-1250.

4. Emlen W, Niebur J, Kadera R: Accelerated in vitro apoptosis of lymphocytes from patients with systemic lupus erythematosus. $J$ Immunol 1994, 152:3685-3692.

5. Perniok A, Wedekind F, Herrmann M, Specker C, Schneider M: High levels of circulating early apoptic peripheral blood mononuclear cells in systemic lupus erythematosus. Lupus 1998, 7:113-118.

6. Baumann I, Kolowos W, Voll RE, Manger B, Gaipl U, Neuhuber WL, Kirchner T, Kalden JR, Herrmann M: Impaired uptake of apoptotic cells into tingible body macrophages in germinal centers of patients with systemic lupus erythematosus. Arthritis Rheum 2002, 46:191-201.

7. Sakaguchi S, Wing K, Miyara M: Regulatory T cells - a brief history and perspective. Eur J Immunol 2007, 37(Suppl 1):S116-S123.

8. Sakaguchi S: Naturally arising Foxp3-expressing $\mathrm{CD} 25^{+} \mathrm{CD} 4^{+}$regulatory $\mathrm{T}$ cells in immunological tolerance to self and non-self. Nat Immunol 2005, 6:345-352

9. Horwitz DA: Regulatory T cells in systemic lupus erythematosus: past, present and future. Arthritis Res Ther 2008, 10:227.

10. Ursaciuc C, Surcel M, Ciotaru D, Dobre M, Pirvu IR, Munteanu AN, Alecu M, Huica R: Regulatory T cells and TH1/TH2 cytokines as immunodiagnosis keys in systemic autoimmune diseases. Roum Arch Microbiol Immunol 2010, 69:79-84.

11. Webb M, Barclay AN: Localisation of the MRC OX-2 glycoprotein on the surfaces of neurones. J Neurochem 1984, 43:1061-1067.

12. Barclay AN, Ward HA: Purification and chemical characterisation of membrane glycoproteins from rat thymocytes and brain, recognised by monoclonal antibody MRC OX 2. Eur J Biochem 1982, 129:447-458.

13. Bukovsky A, Presl J, Zidovsky J, Mancal P: The localization of Thy-1.1, MRC OX 2 and la antigens in the rat ovary and fallopian tube. Immunology $1983,48: 587-596$.

14. Gorczynski R, Chen Z, Kai Y, Lee L, Wong S, Marsden PA: CD200 is a ligand for all members of the CD200R family of immunoregulatory molecules. Immunol 2004, 172:7744-7749.

15. Rijkers ES, de Ruiter T, Baridi A, Veninga H, Hoek RM, Meyaard L: The inhibitory CD200R is differentially expressed on human and mouse $T$ and B lymphocytes. Mol Immunol 2008, 45:1126-1135.

16. Wright GJ, Cherwinski H, Foster-Cuevas M, Brooke G, Puklavec MJ, Bigler M, Song $Y$, Jenmalm M, Gorman D, McClanahan T, Liu MR, Brown MH, Sedgwick JD, Phillips JH, Barclay AN: Characterization of the CD200 receptor family in mice and humans and their interactions with CD200. J Immunol 2003, 171:3034-3046.

17. Cherwinski HM, Murphy CA, Joyce BL, Bigler ME, Song YS, Zurawski SM, Moshrefi MM, Gorman DM, Miller KL, Zhang S, Sedgwick JD, Phillips JH: The
CD200 receptor is a novel and potent regulator of murine and human mast cell function. J Immunol 2005, 174:1348-1356.

18. Hoek RM, Ruuls SR, Murphy CA, Wright GJ, Goddard R, Zurawski SM, Blom B, Homola ME, Streit WJ, Brown MH, Barclay AN, Sedgwick JD: Downregulation of the macrophage lineage through interaction with OX2 (CD200). Science 2000, 290:1768-1771.

19. Broderick C, Hoek RM, Forrester JV, Liversidge J, Sedgwick JD, Dick AD: Constitutive retinal CD200 expression regulates resident microglia and activation state of inflammatory cells during experimental autoimmune uveoretinitis. Am J Pathol 2002, 161:1669-1677.

20. Rosenblum MD, Olasz EB, Yancey KB, Woodliff JE, Lazarova Z, Gerber KA, Truitt RL: Expression of CD200 on epithelial cells of the murine hair follicle: a role in tissue-specific immune tolerance? J Invest Dermatol 2004, 123:880-887.

21. Gorczynski RM, Chen Z, Diao J, Khatri I, Wong K, Yu K, Behnke J: Breast cancer cell CD200 expression regulates immune response to EMT6 tumor cells in mice. Breast Cancer Res Treat 2010, 123:405-415.

22. Moreaux J, Veyrune JL, Reme T, De Vos J, Klein B: CD200: a putative therapeutic target in cancer. Biochem Biophys Res Commun 2008, 366:117-122.

23. Kawai H, Yamada Y, Tatsuka M, Niwa O, Yamamoto K, Suzuki F: Downregulation of nuclear factor kappaB is required for p53-dependent apoptosis in X-ray-irradiated mouse lymphoma cells and thymocytes. Cancer Res 1999, 59:6038-6041.

24. Chrest FJ, Buchholz MA, Kim YH, Kwon TK, Nordin AA: Identification and quantitation of apoptotic cells following anti-CD3 activation of murine G0 T cells. Cytometry 1993, 14:883-890.

25. Darzynkiewicz Z, Bedner E, Smolewski P: Flow cytometry in analysis of cell cycle and apoptosis. Semin Hematol 2001, 38:179-193.

26. Mihrshahi R, Barclay AN, Brown MH: Essential roles for Dok2 and RasGAP in CD200 receptor-mediated regulation of human myeloid cells. J Immunol 2009, 83:4879-4886.

27. Gorczynski RM, Cattral MS, Chen Z, Hu J, Lei J, Min WP, Yu G, Ni J: An immunoadhesin incorporating the molecule OX-2 is a potent immunosuppressant that prolongs allo- and xenograft survival. $J$ Immunol 1999, 163:1654-1660.

28. Gorczynski RM, Chen Z, Yu K, Hu J: CD200 immunoadhesin suppresses collagen-induced arthritis in mice. Clin Immunol 2001, 101:328-334.

29. Chen W, Jin W, Hardegen N, Lei KJ, Li L, Marinos N, McGrady G, Wahl SM: Conversion of peripheral $\mathrm{CD} 4^{+} \mathrm{CD} 25^{-}$naive $\mathrm{T}$ cells to $\mathrm{CD} 4^{+} \mathrm{CD} 25^{+}$ regulatory $T$ cells by TGF-beta induction of transcription factor Foxp3. J Exp Med 2003, 198:1875-1886.

30. Ren Y, Tang J, Mok MY, Chan AW, Wu A, Lau CS: Increased apoptotic neutrophils and macrophages and impaired macrophage phagocytic clearance of apoptotic neutrophils in systemic lupus erythematosus. Arthritis Rheum 2003, 48:2888-2897.

31. Fransen $\mathrm{JH}$, van der Vlag J, Ruben J, Adema GJ, Berden JH, Hilbrands LB: The role of dendritic cells in the pathogenesis of systemic lupus erythematosus. Arthritis Res Ther 2010, 12:207.

32. Jin O, Sun LY, Zhou KX, Zhang XS, Feng XB, Mok MY, Lau CS: Lymphocyte apoptosis and macrophage function: correlation with disease activity in systemic lupus erythematosus. Clin Rheumatol 2005, 24:107-110.

33. Courtney PA, Crockard AD, Williamson K, Irvine AE, Kennedy RJ, Bell AL: Increased apoptotic peripheral blood neutrophils in systemic lupus erythematosus: relations with disease activity, antibodies to double stranded DNA, and neutropenia. Ann Rheum Dis 1999, 58:309-314.

34. Smed-Sorensen A, Lore K, Walther-Jallow L, Andersson J, Spetz AL: HIV-1infected dendritic cells up-regulate cell surface markers but fail to produce IL-12 p70 in response to CD40 ligand stimulation. Blood 2004, 104:2810-2817.

35. Jenmalm MC, Cherwinski H, Bowman EP, Phillips JH, Sedgwick JD: Regulation of myeloid cell function through the CD200 receptor. $J$ Immunol 2006, 176:191-199.

36. Ravichandran KS, Lorenz U: Engulfment of apoptotic cells: signals for a good meal. Nat Rev Immunol 2007, 7:964-974.

37. Petermann KB, Rozenberg Gl, Zedek D, Groben P, McKinnon K, Buehler C, Kim WY, Shields JM, Penland S, Bear JE, Thomas NE, Serody JS, Sharpless NE: CD200 is induced by ERK and is a potential therapeutic target in melanoma. J Clin Invest 2007, 117:3922-3929. 
38. Pallasch CP, Ulbrich S, Brinker R, Hallek M, Uger RA, Wendtner CM: Disruption of $T$ cell suppression in chronic lymphocytic leukemia by CD200 blockade. Leuk Res 2009, 33:460-464.

39. Gorczynski RM, Lee L, Boudakov I: Augmented induction of $\mathrm{CD} 4^{+} \mathrm{CD} 25^{+}$ Treg using monoclonal antibodies to CD200R. Transplantation 2005, 79:1180-1183.

40. Kohut E, Hajdu M, Gergely P, Gopcsa L, Kilian K, Paloczi K, Kopper L, Sebestyen A: Expression of TGF $\beta 1$ and its signaling components by peripheral lymphocytes in systemic lupus erythematosus. Pathol Oncol Res 2009, 15:251-256.

41. Zhou L, Chong MM, Littman DR: Plasticity of $\mathrm{CD}^{+} \mathrm{T}$ cell lineage differentiation. Immunity 2009, 30:646-655.

42. Zhu J, Paul WE: Heterogeneity and plasticity of T helper cells. Cell Res 2010, 20:4-12.

43. Voehringer D, Rosen DB, Lanier LL, Locksley RM: CD200 receptor family members represent novel DAP12-associated activating receptors on basophils and mast cells. J Biol Chem 2004, 279:54117-54123.

44. Gorczynski RM: Thymocyte/splenocyte-derived $\mathrm{CD} 4^{+} \mathrm{CD} 25^{+}$Treg stimulated by anti-CD200R2 derived dendritic cells suppress mixed leukocyte cultures and skin graft rejection. Transplantation 2006, 81:1027-1034

45. Gorczynski RM, Chen Z, Kai Y, Wong S, Lee L: Induction of toleranceinducing antigen-presenting cells in bone marrow cultures in vitro using monoclonal antibodies to CD200R. Transplantation 2004, 77:1138-1144.

\section{doi:10.1186/ar3853}

Cite this article as: Li et al:: Aberrant CD200/CD200R1 expression and function in systemic lupus erythematosus contributes to abnormal Tcell responsiveness and dendritic cell activity. Arthritis Research \& Therapy 2012 14:R123.

\section{Submit your next manuscript to BioMed Central and take full advantage of:}

- Convenient online submission

- Thorough peer review

- No space constraints or color figure charges

- Immediate publication on acceptance

- Inclusion in PubMed, CAS, Scopus and Google Scholar

- Research which is freely available for redistribution

Submit your manuscript at www.biomedcentral.com/submit 